\title{
The relative susceptibility of grapevine rootstocks to black foot disease is dependent on inoculum pressure
}

\author{
Carolyn Bleach, Hayley J. Ridgway ${ }^{\dagger}$, Marlene V. Jaspers and E. Eirian Jones* \\ Department of Pest-management and Conservation, Faculty of Agriculture and Life Sciences, Lincoln University, \\ Lincoln 7647, Canterbury, New Zealand \\ * Current address: Ministry for Primary Industries, PO Box 14018, Christchurch 8544, New Zealand \\ ${ }^{+}$Current address: The New Zealand Institute for Plant \& Food Research Ltd, Private Bag 4704, Christchurch \\ 8140, New Zealand
}

*Corresponding author: Eirian.Jones@lincoln.ac.nz

(Original submission received 24 March 2021; accepted in revised form 13 September 2021)

\begin{abstract}
Black foot disease of grapevines is a major economic issue for the viticulture industry worldwide. The disease is mainly associated with a complex of pathogen species within the genera Dactylonectria and Ilyonectria. The susceptibility of six grapevine rootstock cultivars to black foot disease under field conditions was assessed. Callused rootstocks of 101-14, 5C, 420A, Riparia Gloire, Schwarzmann and 3309C were planted into soil containing low natural pathogen populations or inoculated with isolates representing the species diversity in New Zealand. Disease incidence, disease severity and dry weight accumulation were assessed after 8 months of growth. Root and shoot dry weights were not significantly affected by inoculation treatment, but differed among rootstock cultivars, with cultivar 420A having the lowest root and shoot dry weight, cultivar 3309C having the largest shoot dry weight and cultivar 5C the largest root dry weight. The relative susceptibility of rootstocks differed significantly depending on whether they were grown under low natural inoculum pressure or a higher pressure in artificially inoculated soil. Schwarzmann and Riparia Gloire rootstock cultivars were the least susceptible under natural low inoculum pressure, but were the most susceptible in inoculated soil. In contrast, 5C was one of the most susceptible under low inoculum levels but was the least susceptible under high pathogen pressure. The result of the study indicate that black foot pathogen inoculum levels in soil affect the relative susceptibility of grapevine rootstocks to infection, and may have implications for the selection of rootstocks for planting.
\end{abstract}

Keywords Ilyonectria; Dactylonectria; Cylindrocarpon; disease severity; disease incidence; Vitis spp.

\section{INTRODUCTION}

Black foot disease of grapevines is a major disease found in grape-growing regions worldwide with the disease being most prevalent in nurseries and young grapevines planted in vineyards (Halleen et al. 2006; Úrbez-Torres et al. 2014; Gramaje et al. 2018). Characteristic symptoms of the disease include black discolouration and necrosis of wood tissue, which starts at the base of the rootstock trunk (Halleen et al. 2004). Aboveground, vines often have reduced vigour with shortened internodes and sparse and chlorotic foliage, which is frequently followed by vine death. Decline and death of the vines results in considerable economic losses to the vineyard industry. The causal agents include species of the genera Campylocarpon Halleen, Schroers \& Crous, Cylindrocarpon Wollenw, Cylindrocladiella Boesew., Dactylonectria L. Lombard \& Crous and Ilyonectria P. Chaverri \& C. Salgado (Cabral et al. 2012a, b; Agustí-Brisach \& Armengol 2013; Lombard et al. 2014). In New Zealand,
Ilyonectria, Dactylonectria and Cylindrocladiella species have been identified associated with black foot disease in nurseries and vineyards (Jones et al. 2012; Pathrose 2012; Pathrose et al. 2014; Sheng et al. 2018).

The pathogens are soilborne and can remain in soil after the removal of an infected crop. The pathogen propagules infect grapevine plants through their roots or the basal ends of the grapevine rootstocks planted in pathogeninfested soils (Halleen et al. 2003; Agustí-Brisach \& Armengol 2013). Scheck et al. (1998a) concluded that death seemed to be inevitable when vines less than 10 years of age were infected with black foot pathogens. Currently there are limited strategies that effectively control the disease (Agustí-Brisach \& Armengol 2013). Selection of rootstocks with tolerance to black foot disease has potential to contribute to increased control. In California, Gubler et al. (2004) reported that Vitis riparia rootstocks 039-16 and Freedom had good levels of resistance to a pathogen 
referred to as Cylindrocarpon destructans (now Ilyonectria radicicola species complex). Further, rootstock Riparia was reported to be resistant to black foot disease (Petit 2005, cited in Úrbez-Torres et al. 2014). Jaspers et al. (2007) evaluated the susceptibility of rootstocks commonly used in New Zealand under greenhouse conditions. Results showed that all rootstocks were susceptible to some degree, however Riparia Gloire, R140, 3390C and 420A had the lowest incidence of pathogen recovery. Evaluation of the susceptibility of the most commonly used grapevine rootstocks in Spain under greenhouse conditions found that all rootstocks inoculated with Cylindrocarpon liriodendri (now Ilyonectria liriodendri) and Cylindrocarpon macrodidymum (now Dactylonectria macrodidyma species complex) became infected by the pathogens (Alaniz et al. 2010). However, both the New Zealand study of Jaspers et al. (2007) and the Spanish study of Alaniz et al. (2010) were pot experiments conducted under greenhouse conditions after dipping the rootstocks in pathogen conidial suspension and/or growing them in pathogen-inoculated potting mixture. The relative susceptibility of rootstocks may differ under more natural field conditions (e.g. where they are planted into soil and exposed either to natural inoculum or artificially inoculated), and has not been investigated. The aim of the current study was to determine the relative susceptibility of six grapevine rootstocks commonly grown in New Zealand under field conditions in soil that had a low natural pathogen population and also when inoculated with isolates that represented the diversity of black foot disease pathogen species in New Zealand (Pathrose 2012).

\section{MATERIALS AND METHODS Fungal Isolates}

Nine Ilyonectria/Dactylonectria isolates were used for this study (Table 1). These were representative of isolates isolated from trunks and roots of symptomatic grapevines collected throughout New Zealand shown to be pathogenic (Pathrose 2012; Probst et al. 2019; Outram et al. 2014). The isolates were stored as mycelial discs in glycerol at $-80^{\circ} \mathrm{C}$ until needed, and then subcultured onto potato dextrose agar (PDA; Oxoid Ltd, Basingstoke, Hampshire, England) plates and incubated at $20^{\circ} \mathrm{C}$ under $12 \mathrm{~h}: 12 \mathrm{~h}$ light:dark for 2-4 weeks.

\section{Rootstock material}

Callused rootstocks of cultivars 101-14 Mgt (101-14; Vitis riparia $\mathrm{x} V$. rupestris), Teleki 5C (5C; V. berlandieri $\mathrm{x}$ V. riparia), 420A Mgt (420A; V. berlandieri x V. riparia), Riparia Gloire (V. riparia), Schwarzmann (Vitis riparia $\mathrm{x}$ V. rupestris) and Couderc 3309 (3309C; Vitis riparia $\mathrm{x}$ $V$. rupestris) were supplied by a commercial nursery. All rootstocks were treated with hot water by the nursery prior to supply, as was the standard practice in the nursery. The rootstocks were selected based on the results of Jaspers et al. (2007) indicating they differed in susceptibility to black foot disease.

\section{Field Experiment}

Inoculum production

Conidium suspensions for each isolate were prepared by pipetting $5 \mathrm{~mL}$ sterile distilled water (SDW) (amended with 0.01\% Tween-80; BDH Chemicals Ltd, Poole, England) onto the surface of 10 replicate cultures of each isolate and scraping the colony surface with a sterile glass microscope slide to release the conidia. The contents of the plates for each isolate were then placed in a new plastic bag and emulsified with $100 \mathrm{~mL}$ of SDW using a Colworth Stomacher 400 (A.J. Seward \& Co., Blackfriars Rd, London, UK) set at $50 \mathrm{~Hz}$ for $10 \mathrm{~min}$. A further $500 \mathrm{~mL}$ of SDW was mixed into the resulting mash and strained through a series of sterilised sieves (pore sizes of 710,500 and $150 \mu \mathrm{m}$ ), with the filtrate from the $150-\mu \mathrm{m}$ sieve being collected into a sterile 2 -L bottle. The mash that remained on the first sieve $(710 \mu \mathrm{m})$ was replaced into the plastic bag with a further $100 \mathrm{~mL}$ of SDW and the emulsifying process repeated. The resulting mash was again mixed with $500 \mathrm{~mL}$ of SDW and strained through two sieves (500 $\mu \mathrm{m}$ and $150 \mu \mathrm{m}$ ), combining the final filtrates from the

Table 1 Details of the Ilyonectria and Dactylonectria spp. isolates used in the study and originally isolated from characteristic necrotic lesions on grapevine roots and trunks from different New Zealand vineyard regions.

\begin{tabular}{lll}
\hline Species & Isolate code & Geographic origin \\
\hline Ilyonectria europaea A.Cabral, Rego \& Crous & LUPP1071 (Mar7d) & Marlborough \\
Ilyonectria sp. nov & LUPP989 (WPa2a) & Waipara \\
& LUPP1022 (CO5a) & Central Otago \\
Ilyonectria liriodendri (Halleen, Rego \& Crous) P.Chaverri \& Salgado & LUPP1102 (Mar10j) & Central Otago \\
& LUPP953 (HB1a) & Hawke's Bay \\
Dactylonectria novozelandica (A.Cabral \& Crous) L.Lombard \& Crous & LUPP974 (HB6e) & Hawke's Bay \\
Dactylonectria macrodidyma Halleen, Schroers \& Crous & LUPP1039 Gis3d) & Gisborne \\
& LUPP1120 (Mar14c) & Marlborough \\
\hline
\end{tabular}


$150 \mu \mathrm{m}$ sieves. The conidium concentrations for each isolate were adjusted to $1 \times 10^{4} / \mathrm{mL}$ based on haemocytometer counts to ensure equivalent numbers of conidia for each isolate. The mixed isolate conidial inoculum was prepared by mixing together equal volumes of each isolate conidial suspension.

\section{Field experiment set up}

The experiment was conducted at the Horticulture Research Area of Lincoln University, Canterbury, New Zealand with the field site having no recent history of grapevines. The field site was prepared according to standard nursery practices with the soil being cultivated, then mounded and the mounds covered in black polythene. Irrigation was provided using T-Tape drip tape, model 505 (T-Systems, Australia) installed on the ground under the black polythene. The site was irrigated during the week prior to planting and applied for 30 min per day, which was controlled by an electronic timer. Planting holes were made through the polythene to a depth of $15 \mathrm{~cm}$, in double rows $100 \mathrm{~mm}$ apart. The mixed conidial suspension ( 1 x $10^{4}$ conidia $/ \mathrm{mL}$ of the nine isolates; $20 \mathrm{~mL}$ ) was injected at the base of each planting hole immediately prior to planting using a drench pack and gun suitable for dosing farm animals (NJ Phillips Pty Limited, NSW, Australia). For the untreated control treatment, the equivalent volume of water was injected into each planting hole prior to planting. Apparently healthy, two-node cuttings from the hot-water treated callused rootstocks cultivars were inserted into the planting holes. The experiment was laid out in a completely randomised split-plot design with five blocks, each containing 12 plots (two inoculation treatments by six rootstock varieties) that were $600 \mathrm{~mm}$ long, and separated by $200 \mathrm{~mm}$ buffer zones. The rootstock cuttings were planted in double rows of six plants with $100 \mathrm{~mm}$ between each plant in line with standard nursery practice and the treatment plots were separated by $200 \mathrm{~mm}$. There were 12 plants per plot but only the centre eight plants of each plot were used to assess for effects of infection. The experiment was set up in September 2005 (spring) and harvested in May 2006 (autumn).

\section{Assessment}

After 8 months growth, the plants were uprooted one plot at a time and thoroughly washed with running tap water. The roots and shoots were removed and air-dried separately at $60^{\circ} \mathrm{C}$ to constant weight. The bare trunks were surface sterilised one plot at a time following the method described by Probst et al. (2012). The trunks were soaked sequentially in $70 \%$ ethanol for $30 \mathrm{sec}, 0.35 \%$ sodium hypochlorite for $5 \mathrm{~min}$ and $70 \%$ ethanol for $30 \mathrm{sec}$. The trunks were then dried by placing on paper towels in a laminar-flow cabinet for $10 \mathrm{~min}$. Immediately before isolation, the root crown (which comprised the lowest $1 \mathrm{~cm}$ of the trunk base) was removed. A 1-2 mm section was sliced from across the basal end of each trunk $(0 \mathrm{~cm})$ and divided with four pieces and placed equidistantly around the perimeter of a PDA plate amended with chloramphenicol $(250 \mathrm{mg} / \mathrm{L})$. To assess the progression of the pathogen, another $1-2 \mathrm{~mm}$ slice at $5 \mathrm{~cm}$ above the base was cut into two pieces and one piece placed on the centre of the same plate. After incubation for 7 days at $20^{\circ} \mathrm{C}$ in the dark, Ilyonectria/Dactylonectria-like isolates growing from the wood pieces was assessed. Presence of these pathogens in a trunk was taken as evidence of disease incidence, and the proportion of wood pieces at $0 \mathrm{~cm}$ containing the pathogens as disease severity (Brown et al. 2012; Probst et al., 2012; Brown et al. 2013).

\section{Statistical analysis}

The shoot and root dry weight data per plot were analysed by two-way analysis of variance (ANOVA), with terms appropriate to the design and two-way interactions amongst the factors of interest (cultivar and inoculation). Disease incidence from $0 \mathrm{~cm}$ and $5 \mathrm{~cm}$ isolations (the proportions of plants infected per plot) and disease severity (the proportion of tissue pieces out of 36 infected per plot) were arcsine transformed prior to analysis by ANOVA. Where significant main effects (cultivar and inoculation) or twoway interactions were identified the means were compared Fisher's protected LSD tests at $P \leq 0.05$. All analyses were carried out using GenStat (Version 16, VSN International Ltd, UK).

\section{RESULTS \\ Dry weights}

There was no significant interaction between inoculation and grapevine rootstock cultivar on shoot $(P=0.520)$ or root $(P=0.523)$ dry weights (Figure 1$)$. Inoculation also had no significant effect on shoot $(P=0.488)$ or $\operatorname{root}(P=0.993)$ dry weights, with shoot dry weight being $50.94 \mathrm{~g} /$ plot and $53.25 \mathrm{~g} / \mathrm{plot}$, respectively for uninoculated and inoculated rootstocks and root dry weight being $22.89 \mathrm{~g} / \mathrm{plot}$ and $22.87 \mathrm{~g} / \mathrm{plot}$, respectively for uninoculated and inoculated rootstocks. Cultivar had a significant effect on both shoot $(P<0.001)$ and root $(P<0.001)$ dry weight. The smallest shoot dry weight was for cultivar 420A (19.92 g/plot) which was significantly lower than for all other cultivars. The largest shoot dry weight was for 3309C (70.24 g/plot), 101-14 (66.13 g/plot) and Schwarzmann (63.35 g/plot) which were significantly higher than for $5 \mathrm{C}(49.14 \mathrm{~g} / \mathrm{plot})$ and Riparia Gloire (43.82 g/plot). Cultivar 420A also had the lowest root dry weight $(9.04 \mathrm{~g} / \mathrm{plot})$ which was significantly lower than for all other cultivars. The largest root dry weight was for 5C (31.75 g/plot), 101-14 (28.30 g/plot), which were significantly higher than all other cultivars apart from 3309 (26.92 g/plot).

\section{Disease assessments}

At harvest, typical symptoms of black foot disease was observed on the rootstocks, including vascular discolouration and necrosis of the basal stem tissue. In general, these symptoms were more frequently observed in rootstocks harvested from the inoculated plots, however the incidence or severity of the symptoms on individual plants were not assessed.

\section{Disease Incidence at $\mathbf{0} \mathbf{~ c m}$}

There was a significant interaction $(P<0.001)$ between inoculation and cultivar on disease incidence at $0 \mathrm{~cm}$ above the trunk base (Table 2). Disease incidence was 


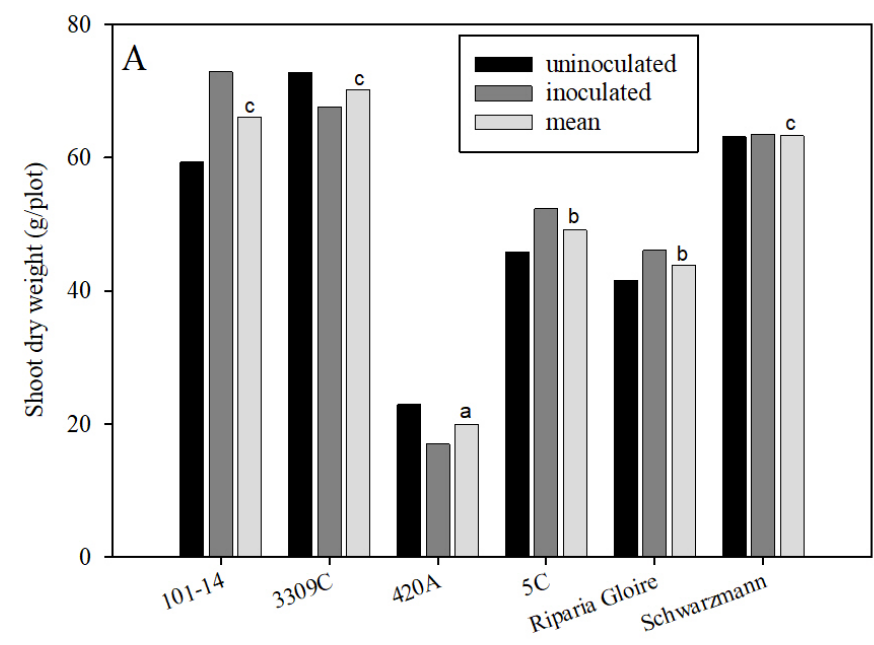

Rootstock cultivar



Rootstock cultivar

Figure 1 Mean (A) shoot and (B) root dry weights (g/plot) for six grapevine rootstock cultivars grown for 8 months in field soil inoculated with a mixture of Ilyonectria/ Dactylonectria species isolates or uninoculated. Mean of 8 rootstocks per plot in each of 5 blocks. Interaction between inoculation and cultivar was not significant for shoot dry weight $(P=0.520)$ and for root dry weight $(P=0.523)$. Mean across inoculation was significant for shoot dry weight $(P<0.001, \mathrm{LSD}=11.51)$ and for root dry weight $(P<0.001, \mathrm{LSD}=6.290)$, with means with the same letter not significantly different $(P \leq 0.05)$.

significantly higher for the inoculated compared with the uninoculated control plots for three rootstocks (101-14, Riparia Gloire and Schwarzmann) but not for the other three (3309C, 420A and 5C). In the uninoculated plots, the lowest disease incidence was for cultivar Schwarzmann $(22.4 \%)$ followed by Riparia Gloire and 3309C (39.6\% and 47.3\%, respectively), which were not significantly different from each other. The highest disease incidence was for cultivar 420A (68.3\%), 5C (50.0\%) and 101-14 (50.0\%), which did not differ significantly from each other but were significantly higher than for Riparia Gloire and Schwarzmann. In the inoculated plots, Schwarzmann had the highest disease incidence (89.9\%) which was significantly higher compared with $5 \mathrm{C}$ but not the other cultivars. There was no significant difference $(P=0.494)$ in incidence across both inoculation treatments among cultivars. Incidence was significantly affected $(P<0.001)$ by inoculation, being significantly higher across all cultivars in the inoculated (77.9\%) compared with the uninoculated treatment (46.1\%).

\section{Disease Severity at $0 \mathrm{~cm}$}

There was a significant interaction $(P=0.004)$ between inoculation and cultivar on disease severity index at $0 \mathrm{~cm}$ above the trunk base (Table 2). Disease severity was significantly higher for all cultivars apart from 5C in the inoculated compared with the uninoculated control plots. For 5C there was no significant difference in the disease severity for the inoculated compared with the uninoculated control plots. In the non- inoculated plots, the lowest disease severity was for cultivar Schwarzmann (11.0\%) followed by Riparia Gloire and 101-14 (18.2\% and 24.6\%, respectively) which were not significantly different from each other. The highest disease incidence was for cultivar 420A (40.1\%) and 5C (31.5\%) which did not differ significantly from each other but were significantly higher than for Schwarzmann. In the inoculated plots, Schwarzmann had the highest disease incidence (66.4\%) which was significantly higher than for 5C (35.8\%) but not compared with the other cultivars (51.3-59.6\%). There was no significant difference $(P=0.275)$ in disease severity across both inoculation treatments between cultivars. Disease severity was significantly affected $(P<0.001)$ by inoculation, being significantly higher across all cultivars in the inoculated (54.8\%) compared with the uninoculated treatment (25.1\%).

\section{Disease Incidence at $5 \mathbf{c m}$}

There was no significant interaction $(P=0.184)$ between inoculation and grapevine rootstock cultivar on the disease incidence (percentage of plants infected) at $5 \mathrm{~cm}$ above the trunk base. The proportion of plants infected/ plot from the uninoculated plots ranged from $0.5 \%$ for Schwarzmann to $29.7 \%$ for $420 \mathrm{~A}$, and for the inoculated plots ranged from $24.1 \%$ for $5 \mathrm{C}$ to $40 \%$ for $3309 \mathrm{C}$ (data not shown). Similarly there was no significant effect of cultivar $(P=0.283)$ on disease incidence at $5 \mathrm{~cm}$. Inoculation had a significant effect $(P<0.001)$ on disease incidence at $5 \mathrm{~cm}$, with significantly higher incidence in rootstocks from the inoculation treatment (32.4\%) compared with those from the uninoculated treatment $(12.7 \%)$. Disease severity at $5 \mathrm{~cm}$ was not assessed.

\section{DISCUSSION}

The study showed that all six rootstocks were susceptible to Ilyonectria/Dactylonectria infection. In inoculated soil, rootstocks Schwarzmann and Riparia Gloire were the most susceptible to black foot infection while 5C and 3309C were the least susceptible. In contrast, $420 \mathrm{~A}$ was the most susceptible rootstock to black foot infection in the uninoculated control soil with low natural disease pressure while Schwarzmann and Riparia Gloire were the least susceptible. Riparia Gloire was reported to not be susceptible to black foot disease by Petit (2005, cited in Úrbez-Torres 
Table 2 Disease incidence (proportion of plants/plot infected with Ilyonectria/Dactylonectria) and disease severity index (proportion of stem pieces infected with Ilyonectria/Dactylonectria) at $0 \mathrm{~cm}$ for six grapevine rootstock cultivars grown for 8 months in field soil inoculated with a mixture of Ilyonectria/Dactylonectria species isolates or uninoculated. Values in parenthesis are arcsine transformations of proportion data of 8 rootstocks per plot in each of 5 blocks.

\begin{tabular}{|c|c|c|c|c|c|c|}
\hline \multirow[t]{2}{*}{ Cultivar } & \multicolumn{3}{|c|}{ Disease incidence (\%) } & \multicolumn{3}{|c|}{ Disease severity (\%) } \\
\hline & Uninoculated & Inoculated & $\begin{array}{l}\text { Mean across } \\
\text { inoculation }^{\mathrm{a}}\end{array}$ & Uninoculated & Inoculated & $\begin{array}{l}\text { Mean across } \\
\text { inoculation }^{\mathrm{a}}\end{array}$ \\
\hline \multirow[t]{2}{*}{$101-14$} & 50.2 & 82.0 & 67.1 & 24.6 & 56.3 & 39.9 \\
\hline & $(0.787) b^{c} c^{c}$ & (1.132)de & $(0.960)$ & $(0.519) a b c^{c}$ & $(0.849) \mathrm{ef}$ & $(0.684)$ \\
\hline \multirow[t]{2}{*}{$3309 C$} & 47.3 & 70.3 & 59.1 & 29.1 & 51.3 & 39.9 \\
\hline & $(0.758) a b c$ & $(0.995) \mathrm{cde}$ & $(0.877)$ & $(0.570) \mathrm{bc}$ & $(0.798) \mathrm{def}$ & $(0.684)$ \\
\hline \multirow[t]{2}{*}{$420 \mathrm{~A}$} & 68.3 & 76.1 & 72.3 & 40.1 & 59.6 & 49.9 \\
\hline & $(0.973) \mathrm{cde}$ & $(1.060) \mathrm{de}$ & $(1.016)$ & $(0.686) \mathrm{cde}$ & $(0.882)$ ef & $(0.784)$ \\
\hline \multirow[t]{2}{*}{$5 C$} & 49.9 & 65.4 & 57.7 & 31.5 & 35.8 & 33.6 \\
\hline & $(0.784) \mathrm{bc}$ & $(0.943) \mathrm{bcd}$ & $(0.863)$ & $(0.596) b c$ & $(0.642) \mathrm{cd}$ & $(0.619)$ \\
\hline \multirow[t]{2}{*}{ Riparia Gloire } & 39.6 & 82.9 & 62.6 & 18.2 & 59.4 & 37.6 \\
\hline & $(0.681) a b$ & (1.145)de & $(0.913)$ & $(0.441) \mathrm{ab}$ & $(0.880)$ ef & $(0.660)$ \\
\hline \multirow[t]{2}{*}{ Schwarzmann } & 22.4 & 89.9 & 56.9 & 11.0 & 66.4 & 36.1 \\
\hline & $(0.493) \mathrm{a}$ & $(1.217) \mathrm{e}$ & $(0.855)$ & $(0.338) \mathrm{a}$ & $(0.952) f$ & $(0.645)$ \\
\hline \multirow[t]{2}{*}{ Mean across cultivarb } & 46.1 & 77.9 & & 25.1 & 54.8 & \\
\hline & $(0.746) \mathrm{A}$ & (1.082)B & & $(0.525) \mathrm{A}$ & $(0.834) \mathrm{B}$ & \\
\hline
\end{tabular}

${ }^{a}$ Mean across inoculation was not significant for disease incidence $(P=0.494)$ or for disease severity $(P=0.275)$.

${ }^{\mathrm{b}}$ Mean across cultivar was significant for disease incidence $(P<0.001, \mathrm{LSD}=0.1103)$, and for disease severity $(P<0.001, \mathrm{LSD}=0.0817)$. Means followed by the same letter are not significantly different $(P \leq 0.05)$.

${ }^{\mathrm{c}}$ Interaction between inoculation and cultivar was significant $(P<0.001, \mathrm{LSD}=0.2703)$ for disease incidence, and $(P=0.004, \mathrm{LSD}=0.2001)$ for disease severity. Means that are followed by the same letter are not significantly different $(P \leq 0.05)$.

et al. 2014), however neither the inoculum concentration nor the inoculation method used in that study were stated. The rootstock 3309C was reported to be highly susceptible to infection by several Cylindrocarpon/Ilyonectria species by Úrbez-Torres et al. (2014). In contrast, rootstock 3309 was intermediate in susceptibility in both inoculated and uninoculated soils in the current study. However, this difference may be due to rootstock treatment - in the current study rootstocks were planted either in naturally infected soil or in soil inoculated at planting whereas ÚrbezTorres et al. (2014) inoculated rootstocks by dipping them into relatively high conidial suspension concentration and planting into potting mixture, and then making comparisons with uninoculated rootstocks.

The level of infection for rootstock 5C was similar in both the inoculated and uninoculated soil; however, it had the lowest level of infection of all cultivars in the inoculated and second highest in the uninoculated soils. In contrast, Schwarzmann and Riparia Gloire had the lowest infection level under natural low inoculum levels, but the highest in inoculated soil. One explanation is a minimum inoculum pressure is needed to overcome the tolerance of rootstocks such as Schwarzmann and Riparia Gloire to low levels of infection by Ilyonectria/Dacylonectria spp. However, once this tolerance is overcome then the disease is able to develop to relatively high levels. This process may be associated with the ability of the pathogens to colonise the plant tissue post infection and also with the resistance of the host plant to pathogen growth. To date, however, there is little information regarding the mechanism of infection and root colonisation by these pathogens and subsequent host defence response in grapevines (Cabral et al. 2012c) let alone in different cultivars. Alternatively, the observed differences in host susceptibility could be due to differences in the species or the relative pathogenicity of the pathogen strains naturally present in the soil and those used in the inoculum, with some cultivars varying in susceptibility to different species/strains. The species present in the naturally infected soil were not determined, but could represent species with relatively lower pathogenicity such as D. pauciseptata (Schroers \& Crous) L.Lombard \& Crous (Sheng et al. 2018) or Cylindrocladiella parva (P.J.Anderson) Boesew. (Brown et al. 2013). In addition, different isolates of a species have been shown to vary in pathogenicity (Cabral et al. 2012c; Pathrose et al. 2014; Probst et al. 2019). The prevalence and relative pathogenicity of species are likely to vary in different viticulture regions/countries, which may explain why the relative susceptibility of grapevines to Cylindrocarpon spp. has been reported to vary between cultivars and countries (Scheck et al. 1998b; Rego et al. 2000; Halleen et al. 2006). For example, New Zealand D. pauciseptata isolates have been reported to be weakly 
pathogenic (Sheng et al. 2018) but other researchers have reported them to be similar in pathogenicity to other fungi associated with black foot disease (Cabral et al. 2012c).

The relative susceptibility or response of the rootstocks does not seem to be correlated with parentage since Schwarzmann, 3309C and 101-14, which have the same parentage (Vitis riparia x V. rupestris; Goldammer 2015) were seen to be highly variable in their relative susceptibility to either the natural background level or the artificial inoculation level. However, 5C and 420A, which are both $V$. berlandieri $\mathrm{x} V$. riparia crosses, were similar in their relative susceptibility.

The relative susceptibility ranking of rootstocks in the inoculation treatment and the control indicated that disease severity and disease incidence at $0 \mathrm{~cm}$ provided similar outcomes. This result is consistent with that observed by Probst et al. (2012) and therefore either measure could be used as proxy for infection. However, disease incidence was greater at $0 \mathrm{~cm}$ than $5 \mathrm{~cm}$ for all rootstocks whether inoculated or not, which indicated that infection occurs through the stem base or roots and subsequently moves up into the trunk. During the assessment of the symptomatic vines, the pathogen was frequently observed to have initiated infection through the roots and trunk base, as observed by the development of lesions. This observation supports previous reports as to the mode of infection of black foot disease (Úrbez-Torres et al. 2014), indicating this to be an important aspect when considering disease management.

Rootstock material was not tested to determine if there was any background infection prior to use, but all the rootstock material was hot-water treated by the nursery to reduce/eliminate any pathogen infections. Hot-water treatment has been shown in other studies to reduce black foot infection of grapevine rootstocks (Bleach et al. 2013). Further, rootstock material obtained from the same nursery and used in glasshouse experiments in another study was shown to be free of infection (Probst et al. 2019). It is expected, therefore, that the rootstocks used in the current study were relatively free of black foot infection and that the infection levels observed in the rootstocks from the noninoculated control plots were due to natural populations of pathogens found in this site. Previous work (Probst et al. 2019) showed that cross contamination can occur through water splash from overhead irrigation so irrigation was provided using drip tape rather than overhead irrigation in the current study and the soil was covered by black plastic to further limit any splash contamination between inoculated to non-inoculated plots.

No reduction in root and shoot dry weight was seen due to soil inoculation. This finding is similar to results of Brown et al. (2012), who reported no reduction in dry weight in inoculated compared with uninoculated soils. In contrast, Alaniz et al. (2010) reported that inoculation with Cylindrocarpon liriodendri (syn. Ilyonectria liriodendri) and Cylindrocarpon macrodidyma (now Dactylonectria macrodidyma species complex) caused significant reductions in shoot and root dry weight. Similarly, Cabral et al. (2012c) reported that root and shoot dry weight of cultivar 1103P was significantly reduced with inoculation with some, but not all, Ilyonectria species isolates from grapevine and non- grapevine hosts. However, the study by Alaniz et al. (2010) was carried out in sterile potting mix, with comparisons made between pathogen inoculated and no pathogen control (sterile system) whereas the current study involved rootstocks planted in field soil with a natural background pathogen level. Although a soil:peat:sand mixture was used in the study of Cabral et al. (2012c), no infection was observed in the uninoculated controls indicating that the black foot pathogen level was low or absent in the soil used.

This is the only reported study where rootstock susceptibility was assessed under a field nursery situation in both inoculated and naturally infested soil, which allowed the comparison of rootstock susceptibility under high and low inoculum pressure respectively. Further, evaluation of the relative susceptibility of grapevine cultivars in non-sterile soil systems is important since soil microbial communities associated with the grapevine rhizosphere under natural conditions could affect susceptibility. Different cultivars are also likely to influence the microbial composition of the rhizosphere soil, attracting different microbial communities due to differences in the quantity and quality of root exudates (Grayston et al. 1998; Garbeva et al. 2004; Morgan et al. 2005; Badri \& Vivanco 2009). Under low natural inoculum levels, these microbial communities associated with certain rootstock cultivars may be able to suppress disease, which these microbial communities are unable to do under high disease pressure.

This study showed that no rootstock was completely resistant to infection under field conditions, although some rootstocks were tolerant to a degree, and that there was a difference in susceptibility to black foot disease depending on the amount of inoculum in the soil. However, physiochemical soil factors such as soil types, $\mathrm{pH}$, soil moisture and nutrient availability are likely to affect relative susceptibility so further work in different field sites is needed to enable recommendations to growers as to the most appropriate rootstock cultivar to plant in a vineyard site with respect to black foot tolerance under different pathogen soil inoculum levels.

\section{ACKNOWLEDGEMENTS}

The authors are grateful to New Zealand Winegrowers for funding and Technology for Industry Funding (Callaghan Innovation), New Zealand Ministry of Science and Innovation for providing a scholarship to the first author, and to Lincoln University field and nursery staff for assistance in setting up and maintenance of the field experiment.

\section{REFERENCES}

Agustí-Brisach C, Armengol J 2013. Black-foot disease of grapevine: and update on taxonomy, epidemiology and management strategies. Phytopathologia Mediterranea 52(2): 245-261.

Alaniz S, García-Jiménez J, Abad-Campos P, Armengol J 2010. Susceptibility of grapevine rootstocks to Cylindrocarpon liriodendri and C. macrodidymum. Scientia Horticulturae 125: $\quad 305-308 . \quad$ https://doi.org/10.1016/j. 


\section{$\underline{\text { scienta.2010.04.009 }}$}

Badri DV, Vivanco JM 2009. Regulation and function of root exudates. Plant, Cell \& Environment 32(6): 666-681. https://doi.org/10.1111/j.1365-3040.2009.01926.x

Bleach CM, Jones EE, Ridgway HJ, Jaspers MV 2013. Hot water treatment to reduce incidence of black foot pathogens in young grapevines grown in cool climates. Phytopathologia Mediterranea 52(2): 347-338.

Brown DS, Jones EE, Ridgway HJ, Jaspers MV 2012. Effect of partial defoliation on Cylindrocarpon destructans infection of grapevine. New Zealand Plant Protection 65: 256-261. https://doi.org/10.30843/ nzpp.2012.65.5378

Brown DS, Jaspers MV, Ridgway HJ, Jones EE 2013. Susceptibility of grapevine rootstocks to Cylindrocladiella parva. New Zealand Plant Protection 66: 249-253. https://doi.org/10.30843/nzpp.2013.66.5675.

Cabral A, Groenewald JZ, Rego C, Oliveria H, Crous PW 2012a. Cylindrocarpon root rot: multi-gene analysis reveals novel species within the Ilyonectria radicicola species complex. Mycological Progress 11: 655-688. https:// doi.org/10.1007/s11557-011-0777-7

Cabral A, Rego C, Nascimento T, Oliveria H, Groenewald JZ, Crous PW 2012b. Multi-gene analysis and morphology revela novel Ilyonectria species associated with black foot disease of grapevines (Vitis spp.). Fungal Biology 116: 62-80. https://doi.org/10.1016/j.funbio.2011.09.010

Cabral A, Rego C, Crous PW, Oliveira H 2012c. Virulence and cross-infection potential of Ilyonectria spp. to grapevine. Phytopathologia Mediterranea 51(2): 340-354.

Cardoso M, Diniz I, Cabral A, Rego C, Oliveira H 2013. Unveiling inoculum sources of black foot pathogens in a commercial grapevine nursery. Phytopathologia Mediterranea 52(2): 298-312.

Garbeva P, van Veen JA, van Elsas JD 2004. Microbial diversity in soil: selection of microbial populations by plant and soil type and implications for disease suppressiveness. Annual Review of Phytopathology 42: 243-270. https:// doi.org/10.1146/annurev.phyto.42.012604.135455

Goldammer T 2015. The Grape Grower's handbook. Second Edition Virginia USA: Apex Publishers.

Gramaje D, Úrbez-Torres JR, Sosnowski MR 2018. Managing grapevine trunk diseases with respect to etiology and epidemiology: current strategies and future prospects. Plant Disease 102: 12-39. https://doi.org/10.1094/ PDIS-04-17-0512-FE

Grayston SJ, Wang SQ, Campbell CD, Edwards AC 1998. Selective influence of plant species on microbial diversity in the rhizosphere. Soil Biology and Biochemistry 30(3): 369-378. https://doi.org/10.1016/S00380717(97)00124-7

Gubler WD, Baumgartner K, Browne GT, Eskalen A, Rooney Latham S, Petit E, Bayramian LA 2004. Root disease of grapevines in California and their control. Australasian Plant Patholology 31: 57-165. https://doi.org/10.1071/ $\underline{\mathrm{AP} 04019}$
Halleen F, Crous PW, Petrini 0 2003. Fungi associated with healthy grapevine cuttings in nurseries, with special reference to pathogens involved in the decline of young vines. Australasian Plant Pathology 32: 47-52. https:// doi.org/10.1071/AP02062

Halleen F, Schroers H-J, Crous PW 2004. Novel species of Cylindrocarpon (Neonectria) and Campylocarpon gen. nov. associated with black foot disease of grapevines (Vitis spp.). Studies in Mycology 50: 431-455.

Halleen F, Fourie PH, Crous PW 2006. A review of black foot disease of grapevines. Phytopathologia Mediterranea 45: S55-S67.

Jaspers MV, Bleach CM, Harvey IC. 2007. Susceptibility of grapevine rootstocks to Cylindrocarpon disease. Phytopathologia Mediterranea 46: 114. https://doi. org/10.1094/PDIS-04-11-0347

Jones EE, Brown DS, Bleach CM, Pathrose B, Barclay C, Jaspers MV, Ridgway HJ 2012. First report of Cylindrocladiella parva as a grapevine pathogen in New Zealand. Plant Disease 96(1): 144.

Lombard L, Van der Merwe NA, Groenewald JZ, Crous PW 2014. Lineages in Nectriaceae: re-evaluating the generic status of Ilyonectria and allied genera. Phytopathologia Mediterranea 53(3): 515-532.

Morgan JAW, Bending GD, White PJ 2005. Biological costs and benefits to plant-microbe interactions in the rhizosphere. Journal of Experimental Botany 56(417): 1729-1739. https://doi.org/10.1093/jxb/eri205

Outram MA, Jones EE, Jaspers MV, Ridgway HJ 2014. Development of a PCR-RFLP method to distinguish species within the Ilyonectria macrodidyma complex. New Zealand Plant Protection 67:1 51-156. https://doi. org/10.30843/nzpp.2014.67.5746

Pathrose B 2012. Characterising sub-species variation in New Zealand Cylindrocarpon species that cause black foot of grapevines. PhD thesis, Lincoln, New Zealand: Lincoln University. https://researcharchive.lincoln. ac.nz/handle/10182/5517

Pathrose B, Jones EE, Jaspers MV, Ridgway HJ 2014. High genotypic and virulence diversity in Ilyonectria liriodendri isolates associated with black foot disease in New Zealand vineyards. Plant Pathology 63(3): 613624. https://doi.org/10.1111/ppa.12140

Probst C, Jones EE, Ridgway HJ, Jaspers MV 2012. Cylindrocarpon black foot in nurseries - two factors that can increase infection. Australasian Plant Pathology 41: 157-163. https://doi.org/10.1007/s13313-011-0103$\underline{5}$

Probst C, Ridgway HJ, Jaspers MV, Jones EE 2019. Pathogenicity of Ilyonectria liriodendri and Dactylonectria macrodidyma propagules in grapevines. European Journal of Plant Pathology 154: 405-421. https://doi.org/10.1007/s10658-018-01664-0

Rego C, Oliveira H, Carvalho A, Phillips A 2000. Involvement of Phaeoacremonium spp. and Cylindrocarpon destructans with grapevine decline in Portugal. Phytopathologia Mediterranea 39: 76-79. 
Scheck H, Vasquez S, Fogle D, Gubler WD 1998a. Grape growers report losses to black-foot and grapevine decline. California Agriculture 52 (4):19-23. https:// doi.org/10.3733/ca.v052n04p19

Scheck HJ, Vasquez SJ, Gubler WD 1998b. First report of black-foot disease caused by Cylindrocarpon obtusisporum of grapevine in California. Plant Disease 82: 448. https://doi.org/10.1094/PDIS.1998.82.4.448A

Sheng Y, Jones EE, Ridgway HJ 2018. Two genetically distinct groups of Dactylonectria pauciseptata are associated with black foot disease in New Zealand. New Zealand Plant Protection 71: 1-9. https://doi.org/10.30843/ nzpp.2018.71.157

Úrbez-Torres JR, Haag P, Bowen P, O'Gorman DT 2014. Grapevine trunk disease in British Columbia: Incidence and characterization of the fungal pathogens associated with black foot disease of grapevine. Plant Disease 98(4): 456-468. https://doi.org/10.1094/PDIS-05-130524-RE 